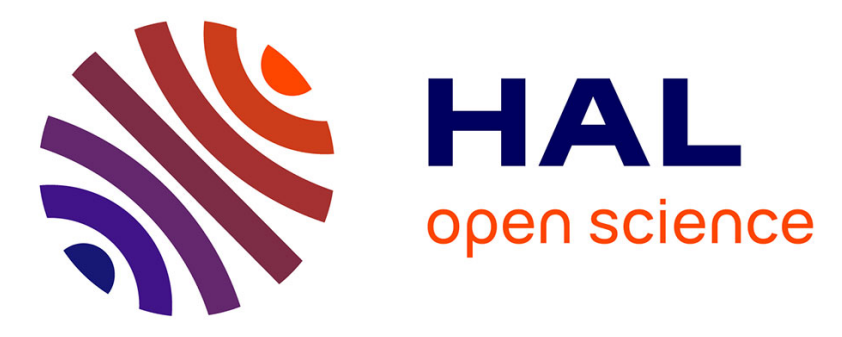

\title{
Specific transgene expression in mouse pancreatic $\beta$-cells under the control of the porcine insulin promoter
}

\author{
Marjeta Grzech, Maik Dahlhoff, Nadja Herbach, Felix A. Habermann, Ingrid
}

Renner-Müller, Rüdiger Wanke, Heinrich Flaswinkel, Eckhard Wolf, Marlon

R. Schneider

\section{To cite this version:}

Marjeta Grzech, Maik Dahlhoff, Nadja Herbach, Felix A. Habermann, Ingrid Renner-Müller, et al.. Specific transgene expression in mouse pancreatic $\beta$-cells under the control of the porcine insulin promoter. Molecular and Cellular Endocrinology, 2009, 315 (1-2), pp.219. 10.1016/j.mce.2009.08.001 . hal-00547653

\section{HAL Id: hal-00547653 \\ https://hal.science/hal-00547653}

Submitted on 17 Dec 2010

HAL is a multi-disciplinary open access archive for the deposit and dissemination of scientific research documents, whether they are published or not. The documents may come from teaching and research institutions in France or abroad, or from public or private research centers.
L'archive ouverte pluridisciplinaire HAL, est destinée au dépôt et à la diffusion de documents scientifiques de niveau recherche, publiés ou non, émanant des établissements d'enseignement et de recherche français ou étrangers, des laboratoires publics ou privés. 


\section{Accepted Manuscript}

Title: Specific transgene expression in mouse pancreatic $\beta$-cells under the control of the porcine insulin promoter

Authors: Marjeta Grzech, Maik Dahlhoff, Nadja Herbach, Felix A. Habermann, Ingrid Renner-Müller, Rüdiger Wanke, Heinrich Flaswinkel, Eckhard Wolf, Marlon R. Schneider

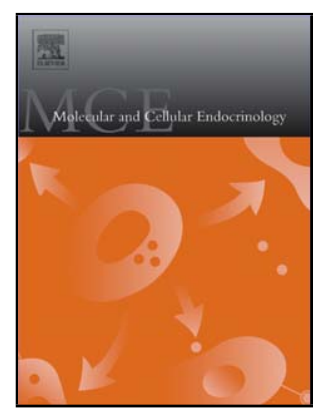

PII: S0303-7207(09)00407-9

DOI: doi:10.1016/j.mce.2009.08.001

Reference: MCE 7284

To appear in: $\quad$ Molecular and Cellular Endocrinology

Received date: $\quad$ 16-6-2009

Revised date: $\quad$ 29-7-2009

Accepted date: $\quad$ 5-8-2009

Please cite this article as: Grzech, M., Dahlhoff, M., Herbach, N., Habermann, F.A., Renner-Müller, I., Wanke, R., Flaswinkel, H., Wolf, E., Schneider, M.R., Specific transgene expression in mouse pancreatic $\beta$-cells under the control of the porcine insulin promoter, Molecular and Cellular Endocrinology (2008), doi:10.1016/j.mce.2009.08.001

This is a PDF file of an unedited manuscript that has been accepted for publication. As a service to our customers we are providing this early version of the manuscript. The manuscript will undergo copyediting, typesetting, and review of the resulting proof before it is published in its final form. Please note that during the production process errors may be discovered which could affect the content, and all legal disclaimers that apply to the journal pertain. 


\title{
Specific transgene expression in mouse pancreatic $\beta$-cells under
}

\section{the control of the porcine insulin promoter}

\author{
Marjeta Grzech ${ }^{1}$, Maik Dahlhoff ${ }^{1}$, Nadja Herbach ${ }^{2}$, Felix A. Habermann ${ }^{3}$, \\ Ingrid Renner-Müller ${ }^{1}$, Rüdiger Wanke ${ }^{2}$, Heinrich Flaswinkel ${ }^{1}$, \\ Eckhard Wolf ${ }^{1,4}$, Marlon R. Schneider ${ }^{1}$
}

${ }^{1}$ Chair for Molecular Animal Breeding and Biotechnology, ${ }^{4}$ and Laboratory for Functional Genome Analysis (LAFUGA), Gene Center, LMU Munich, Munich, Germany;

${ }^{2}$ Institute of Veterinary Pathology, Center for Clinical Veterinary Medicine, LMU Munich, Munich, Germany;

${ }^{3}$ Chair for Veterinary Anatomy, Histology and Embryology, Department of Veterinary Sciences, LMU Munich, Munich, Germany

Address all correspondence to:

Dr. Marlon R. Schneider, Chair for Molecular Animal Breeding and Biotechnology, Gene Center, LMU Munich, Feodor-Lynen-Str. 25, 81377 Munich, Germany, Telephone: +49 89 218076815, Fax: +49 89 218076849, e-mail: schnder@Imb.uni-muenchen.de 


\section{Abstract}

The availability of regulatory sequences directing tissue-specific expression of transgenes in genetically modified mice and large animals is a prerequisite for the development of adequate models for human diseases. The rat insulin 2 gene (Ins2) promoter, widely used to achieve transgene expression in pancreatic $\beta$-cells of mice, also directs expression to extrapancreatic tissues and performs poorly in isolated pancreatic islets of human, mouse, and pig. To evaluate whether the full 5' untranslated region (UTR) of the porcine insulin gene (INS) confers robust and specific expression in $\beta$-cells we generated an expression cassette containing $1500 \mathrm{bp}$ of the porcine INS 5' UTR and the 3' UTR of the bovine growth hormone gene $(G H)$. The cassette was designed to allow easy exchange of the sequences to be expressed and easy removal of the vector backbone from the expression cassette. To evaluate the properties of the cassette, we initially cloned a cDNA encoding human betacellulin, a growth factor known to affect structural and functional parameters of $\beta$-cells. After confirming the functionality and specificity of the construct in vitro, transgenic mouse lines were generated by pronuclear DNA microinjection. Using RT-PCR, immunohistochemistry and immunofluorescence, we show that transgenic mice expressed human betacellulin exclusively in $\beta$-cells. Confirming the proposed insulinotropic effect of betacellulin, transgenic mice showed improved glucose tolerance. We conclude that the newly designed expression cassette containing $1.500 \mathrm{bp}$ of the porcine insulin promoter 5' UTR confers robust and specific transgene expression to $\beta$-cells in vitro and in transgenic mice.

Keywords: porcine insulin promoter, transgenic mice, betacellulin, EGFR, glucose tolerance test. 


\section{INTRODUCTION}

Genetically modified mice greatly contributed to advance our understanding of the physiology and pathology of the endocrine pancreas. A key component of this technology is the targeted expression of gene products in specific cell types of the pancreatic islets. The rat (Dahl et al. 1996; Hanahan 1985; Vasavada et al. 1996), mouse (Hara et al. 2003), and human (Hotta et al. 1998; Krakowski et al. 1999) insulin promoters have been frequently used to direct expression of oncogenes, hormones, growth factors, transcription factors, reporter genes, and more recently of the enzyme Cre recombinase (Ahlgren et al. 1998; Dor et al. 2004; Gannon et al. 2000; Postic et al. 1999) specifically to pancreatic $\beta$-cells in transgenic mice. A major caveat of the rat insulin promoter, however, is the reported ectopic expression in certain areas of the brain, potentially resulting in phenotypes in both $\beta$-cells and neural cells (Gannon et al. 2000; Martin et al. 2003).

While the mouse model is appropriate for answering basic questions of $\beta$-cell pathophysiology, translational studies, particularly regarding islet transplantation, would greatly benefit from large animal models. Pigs seem to be the best candidates for this purpose: they are readily available, produce a large progeny, and regulate blood glucose levels similarly to humans. In addition, porcine neonatal islet cell clusters (Cardona et al. 2006; MacKenzie et al. 2003) and islets from adult pigs (Hering et al. 2006) are an interesting source of insulin-producing tissue for transplantation purposes. In this regard, there is an urgent need of genetic tools for the tissue-specific delivery of gene products to porcine pancreatic $\beta$-cells. Unfortunately, the rat insulin promoter was shown to perform very poorly in isolated islets from pigs, human, and mice (Londrigan et al. 2007). The porcine insulin gene (INS) contains three exons and two introns, and highly conserved cis-acting elements were identified in the 5' flanking region (Han \& Tuch 2001). Recently, a fragment of the porcine INS promoter containing approximately $680 \mathrm{bp}$ of the 5 ' untranslated region (UTR) was active in a cell type-specific manner in vitro, but failed to confer expression in transgenic mice (Watanabe et al. 2007). Addition of a cytomegalovirus enhancer resulted in transgene expression both in vivo and in vitro, but at the expense of cell type specificity (Watanabe et al. 2007). Here, we report that an expression cassette containing $1500 \mathrm{bp}$ of the 5' UTR from the porcine INS gene (including the first exon and the first intron) and the 3' UTR of the bovine growth hormone gene $(G H)$ is efficient to drive transgene expression in a robust and specific manner to $\beta$ cells in vitro and in transgenic mouse models. To test the functionality of the cassette we 
have chosen the cDNA encoding human betacellulin, a ligand of the EGFR (Schneider \& Wolf 2009) known to stimulate $\beta$-cell differentiation in vitro and to improve glucose tolerance in diabetic models and in transgenic mice.

\section{MATERIALS AND METHODS}

\subsection{Construction of the transgene}

A 1500-bp fragment of the 5' flanking region of the porcine insulin gene (INS) was amplified by polymerase chain reaction (Expand High Fidelity ${ }^{\text {PLUS }}$ PCR System, Roche Diagnostics, Mannheim, Germany) using the sense primer (Sall restriction site underlined) 5'-TGT ACT GTC GAC GAG TTC AGC TGA GCT GGC TC-3' and the antisense primer (Hindlll restriction site underlined) 5'-CGC TAG AAG CTT TGG GGG ACG GGC GGC GTT-3' (see Figure 1A). Template was a plasmid pGEM+INS (Flaswinkel et al., unpulished) containing the whole porcine INS gene. The human (h) betacellulin (BTC) cDNA was amplified with the same PCR system employing the pTB 1560 vector (a gift of Dr. Y. Shing, Children's Hospital, Boston, MA) as a template and the primers (Hindll restriction site underlined) 5'-ACT AAG CTT CAC CCC CCG CCA TGG ACC GGG CCG CCC GGT-3', sense, and (ECORV restriction site underlined, HA-tag in bold) 5'-TAG GAT ATC TTA AGC GTA GTC TGG GAC GTC GTA TGG GTA AGC AAT ATT TGT CTC TTC AAT ATC-3', antisense.

The PCR products were cloned into the pCRII-TOPO vector (Invitrogen, Carlsbad, CA) and Sp6/T7-sequenced to confirm amplification fidelity. The porcine INS promoter (PIP) was then subcloned into the Sall and Hindll sites of a pBluescript vector (Stratagene, La Jolla, CA) containing the bovine (b) GH3' untranslated region and polyadenylation signal (pA) within its Xbal and Notl sites (Figure 1B). Next, the BTC cDNA was cloned as a HindlIIEcoRV fragment between PIP and bGHpA (Figure 1B). Correct positioning of each element was confirmed by restriction enzyme digests and sequencing from the PIP through the hBTC cDNA into the bGHpA using the primer 5'CATCTCGGCAGGAGGACGT-3' (Figure 1A).

\subsection{Cell transfection}

All cell culture reagents were purchased from PAA (Pasching, Austria). Immortalized mouse hepatocytes (a gift from Dr. D. Accili, Columbia University, NY), human embryonal kidney 293 cells (HEK 293), and the MIN-6 mouse pancreatic $\beta$-cell line (a gift from Dr. J. Miyazaki, Osaka University) were cultured in low glucose (1 g/L) DMEM medium with 
$10 \%$ fetal bovine serum. $2 \times 10^{6}$ cells were transfected either with the PIP-hBTC construct or with the pGMAX-GFP vector using the Amaxa Nucleofector system (Lonza, Cologne, Germany). After transfection cells were cultured in high glucose medium ( $4.5 \mathrm{~g} / \mathrm{L})$ for 48 hours and harvested for protein isolation.

\subsection{Western blot analyses}

Cells were homogenized in lysis buffer (Cell Signaling, Danvers, MA, USA) and $30 \mu \mathrm{g}$ total protein were separated by SDS-PAGE and transferred to PVDF membranes by electroblotting. Loading of equal amounts of protein for each sample was verified with Ponceau staining. A rabbit antibody that reacts specifically with human BTC (R\&D, Systems, Wiesbaden, Germany) and a secondary HRP-conjugated goat anti-rabbitantibody (Cell Signaling) were employed. Bound antibodies were detected using an enhanced chemiluminescence detection reagent (ECL Advance Western Blotting detection kit, GE Healthcare) and appropriate x-ray films (GE Healthcare).

\subsection{Generation of transgenic mice}

The PIP-hBTC expression cassette was released from the vector backbone by Sall/Notl double digestion, purified by agarose gel electrophoresis, diluted to $2 \mathrm{ng} / \mu \mathrm{l}$ in injection buffer (Nagy et al. 2003) and employed for pronuclear microinjection into fertilized oocytes from the inbred strain FVB/N. The injected zygotes were transplanted into the oviducts of pseudopregnant females and potential founder animals were screened by PCR. The animals had free access to a standard rodent diet (V1534, Ssniff, Soest, Germany) and water. All experiments were approved by the author's institutional committee on animal care and carried out in accordance with the German Animal Protection Law with permission from the responsible veterinary authority.

\subsection{Immunohistochemistry and immunofluorescence}

Animals were anesthetized and killed by cervical dislocation. Pancreata and other organs were removed immediately after the animal's death, carefully trimmed free of adjacent tissues, weighed, fixed in $4 \%$ paraformaldehyde (in PBS, $\mathrm{pH} 7.4$ ) and embedded in paraffin. For immunohistochemical localization of BTC, the streptavidin-biotin method was applied. Five $\mu \mathrm{m}$ thick sections were cut, deparaffinized and heated for $20 \mathrm{~min}$ in a microwave in $10 \mathrm{mM}$ sodium citrate buffer for antigen retrieval. The primary antibody (same as for Western blot, dilution 1:300) was incubated for 2 hours at room temperature, followed by a biotin-conjugated rabbit anti-goat secondary antibody (Dako, Hamburg, 
Germany). Diaminobenzidine (Sigma, Taufkirchen, Germany) served as chromogen. Finally, the sections were counterstained with hematoxylin. Colocalization of BTC with insulin and glucagon was studied by multicolor immunofluorescence: Five $\mu \mathrm{m}$ paraffin sections pretreated as described above were incubated for 1 hour at room temperature with the primary antibodies diluted in Tris-buffered saline (TBS, $\mathrm{pH}$ 7.6). After three washes with TBS, sections were incubated for 1 hour with fluorescence-labeled secondary antibodies. We used the previously described goat anti-human BTC antibody (R\&D, Systems, Wiesbaden, Germany), rabbit anti-glucagon and guinea pig anti-insulin antibodies (Dako, Hamburg, Germany). The secondary antibodies all raised in donkey and coupled to FITC, Cy3, or Cy5 were from Dianova (Hamburg, Germany). After the last washing step, slides were mounted with Vectashield antifade solution (Vector Laboratories, Gr nberg, Germany) containing DAPI as a nuclear counterstain. Confocal optical sections (pixel size $50 \times 50 \mathrm{~nm}$, pinhole size 1 Airy unit corresponding to an optical thickness of $0.7-1 \mu \mathrm{m}$ ) were recorded using a confocal laser scanning microscope (LSM 510 Meta, Zeiss, Oberkochen, Germany) with a $40 \times$ PlanNeofluar oil immersion objective (NA 1.3). For excitation of DAPI, FITC, TRITC and Cy5 laser lines of 364, 488, 543 and $633 \mathrm{~nm}$ were used. Fluorescence signals were detected through the following emission filters: BP 385 - 470 nm for DAPI, BP 505 - 530 nm for FITC, BP 560 - 615 for Cy3 and LP 650 for Cy5. A polychromatic multichannel detector (Meta detector, Zeiss) was used to discriminate autofluorescence from immunofluorescence signals.

\subsection{Reverse transcriptase PCR}

Isolation of total RNA, first strand cDNA synthesis, and semiquantitative RT-PCR were performed as described earlier (Schneider et al. 2001). The primers previously described for amplifying the human BTC cDNA were employed for the detection of transgenespecific BTC mRNA expression. The integrity of the template cDNA was confirmed by amplifying a sequence of the $\beta$-actin gene (sense, 5'-GGCATCGTGATGGACTCC-3'; antisense, 5'-GTCGGAAGGTGGACAGGG-3').

\subsection{Glucose metabolism studies}

After fasting for 14 hours, blood was drawn from the retro-orbital sinus of ether anesthetized mice for determination of blood glucose. For glucose tolerance test, fasted mice (16 hours) were injected intraperitoneally with glucose $(1.5 \mathrm{~g} / \mathrm{kg}$ body weight). Blood samples were obtained by puncture of the tail vein immediately before glucose 
administration and at the indicated time points after injection. A glucometer (Precision, Abbott Diabetes Care, Wiesbaden, Germany) was used to determine glucose levels.

\subsection{Statistical analysis}

The results of glucose tolerance tests were statistically evaluated by analysis of variance (Linear Mixed Models; SAS 8.2; PROC MIXED), taking the fixed effects of Group (transgenic vs. control), Time (relative to glucose application) and the interaction Group*Time as well as the random effect of Animal into account (Verbeke \& Molenberghs 2001).

\section{RESULTS}

\subsection{Evaluation of promoter activity in vitro}

To evaluate the overall functionality and specificity of the construct, cell lines representing different cell types were transfected either with the PIP-hBTC or with the pMAX-GFP vector. Transfection efficiency, evaluated 24 hours after the transfection by monitoring GFP fluorescence, was similar for all lines ( $\sim 50 \%$ green cells, data not shown). After 48 hours, cells transfected with PIP-hBTC were harvested for protein isolation and subjected to Western blot analysis employing an antibody that recognizes specifically human BTC. As shown in Figure 1C, human BTC was clearly detected in protein extracts from mouse MIN-6 $\beta$-cells, but not in extracts from mouse hepatocytes or human embryonic kidney (HEK 293) cells. These in vitro findings indicate that the PIP-hBTC construct is functional and suggest that the employed porcine insulin promoter is selectively activated in $\beta$-cells.

\subsection{Generation of PIP-hBTC transgenic mice}

After microinjection of the PIP-hBTC construct, forty mice were born and three of them were identified as being transgenic by PCR and Southern blot analyses (data not shown). One transgenic animal (\#11) consistently failed to generate transgenic progeny and was therefore sacrificed. The remaining two founders (\#16 and \#38) transmitted the transgene to their descendents in a mendelian fashion, originating two PIP-hBTC transgenic lines (L2 and L3, respectively).

3.3 Specific expression of the PIP-hBTC transgene in insulin-positive cells of the endocrine pancreas 
To evaluate expression of the construct in different organs, RT-PCR analysis was performed for RNA samples from lung, liver, small intestine, kidney, muscle, and pancreatic islets. As shown in Figure 2A, transgene expression was detected exclusively in the pancreatic islets of L2 transgenic mice. The same result was obtained for L3 mice (data not shown). Immunohistochemistry against hBTC also failed to detect positive cells in the above mentioned and additional organs such as the heart, stomach and brain (data not shown). To evaluate whether the used porcine insulin promoter directs expression to certain regions of the ventral brain, as described for the rat insulin promoter (Gannon et al. 2000), we additionally studied the pons, caudate putamen, and the hypothalamus. In none of these brain regions we detected transgene transcripts by RT-PCR (Figure 2B) or hBTC by immunohistochemistry (data not shown). In the pancreas of L2 and L3 transgenic mice, hBTC-positive cells were readily detected within the islets, but not in the exocrine compartment (Figure 2C). The number of cells expressing the transgene was considerably higher in the islets of L3 transgenic mice as compared to founder \#11 and L2 animals (Figure 2D). To further evaluate whether the employed PIP sequence specifically directs expression of the transgene to insulin-producing cells, we examined colocalization of hBTC with insulin and glucagon by multicolor immunofluorescence and confocal laser scanning microscopy. In both transgenic PIP-hBTC and non-transgenic control mice, insulin-specific immunofluorescence was evident in the cytoplasm of the majority of islets cells, while a smaller proportion of the cells was negative for insulin and positive for glucagon (Figure 2E). Importantly, in transgenic animals, hBTC staining was only observed in insulin-positive cells, indicating that the PIP sequence employed is adequate for targeting exclusively pancreatic $\beta$-cells (Figure $2 \mathrm{E}$ ). Evaluation of pancreatic islets from transgenic fetuses sacrificed on day 17.5 of pregnancy revealed that the $\beta$-cell specificity of the employed promoter is already present at this early stage of islet formation (Figure 2F).

\subsection{PIP-hBTC transgenic mice show no overt phenotypic abnormalities}

Transgenic mice from both lines developed normally, were fertile, and did not show any obvious abnormalities. Histological analysis of the pancreas did not reveal any pathological alteration in PIP-hBTC transgenic mice, in agreement with our previous results in mice with overexpression of BTC in both the endocrine and the endocrine compartment (Dahlhoff et al. 2009). Body and organ weights were evaluated in transgenic males and females and gender-matched littermates at the age of 5 months 
( $n=4-6 / g r o u p)$. No differences were observed in total body weight, and in absolute or relative organ weights, irrespective of the line (data not shown).

\subsection{PIP-hBTC transgenic mice show improved glucose tolerance}

Intraperitoneal glucose tolerance tests showed that the blood glucose concentrations rose similarly in control and in PIP-hBTC transgenic mice from line 2 and 3 after glucose injection (Figure 3A). However, glucose clearance was improved in transgenic mice from both lines in the second half of the test period (Figure $3 \mathbf{A}$ ). When the results were expressed as area under the glucose curve, a significant difference was observed between L2 and L3 transgenic mice and their control littermates, respectively (Figure 3B).

\section{DISCUSSION}

Here we show that an expression cassette containing 1500 bp of the 5' UTR from the porcine insulin gene (including the first exon and the first intron) and the 3' UTR of the bovine $\mathrm{GH}$ gene is efficient for driving transgene expression in a robust and specific manner to $\beta$-cells in vitro and in transgenic mice.

To test the functionality of the cassette we have chosen a cDNA encoding the EGFR ligand betacellulin (Schneider \& Wolf 2009). Betacellulin is known to stimulate $\beta$-cell differentiation in vitro and to improve glucose tolerance in diabetic models and in transgenic mice (reviewed in (Dahlhoff et al. 2009) - although a few studies failed to demonstrate such an effect (Sjoholm \& Kindmark 1999). Recently, we demonstrated an improved glucose tolerance in mice with ubiquitous overexpression of betacellulin (Dahlhoff et al. 2009; Schneider et al. 2005). This finding needed cautious interpretation, since betacellulin levels were also higher in other tissues. In the present study we demonstrate an improved glucose tolerance in an animal model with $\beta$-cell-specific overexpression of betacellulin. Also in agreement with our previous results is the lack of pathological alterations in PIP-hBTC transgenic mice. This is in contrast to the multiple pathological effects including islet disaggregation, fibrosis, and even ductal metaplasia observed in transgenic mice with $\beta$-cell-specific overexpression of the EGFR ligands EGF (Krakowski et al. 1999) and heparin-binding EGF (Means et al. 2003). This observation indicates that BTC has unique actions on pancreatic islets as compared to other EGFR ligands. The transgenic mouse lines described here are valuable for detailed studies of 
glucose metabolism and $\beta$-cell regeneration following induction of diabetes e.g. after injection of streptozotocin.

The new expression cassette described here represents a significant improvement over available expression systems in different ways. First, our cassette potentially allows $\beta$ cell-specific expression of gene products in transgenic mice without the unwanted expression in other tissues such as the central nervous system. Nevertheless, the level and specificity of transgene expression in new lines are always difficult to predict due to position effects and require careful characterization (Martin \& Whitelaw 1996). Second, the ease of exchanging the sequences to be expressed in the cassette and the availability of restriction sites for "rare cutter" enzymes for removing the relevant sequences from the vector backbone render this construct a handy tool for the generation of transgenic mice for $\beta$-cell specific overexpression of a variety of proteins. Third, it is plausible to predict that the transgene cassette will also perform well in pigs, promoting a widespread use of this species in diabetes research. 


\section{ACKNOWLEDGEMENTS}

We are grateful to Dr. S. Lortz (Hannover Medical School, Germany), Dr. J. Miyazake (Osaka Univeristy), and Dr. D. Accili (Columbia University, NY) for cell lines. We thank Petra Renner for animal care and Josef Millauer for routine mouse genotyping. This study was supported by the Deutsche Forschungsgemeinschaft (DFG, GRK 1029 and FOR 535). 


\section{REFERENCES}

Ahlgren, U., Jonsson, J., Jonsson, L., Simu, K., and Edlund, H. 1998 beta-cell-specific inactivation of the mouse Ipf1/Pdx1 gene results in loss of the beta-cell phenotype and maturity onset diabetes. Genes Dev. 12, 1763-1768.

Cardona, K., Korbutt, G. S., Milas, Z., Lyon, J., Cano, J., Jiang, W., Bello-Laborn, H., Hacquoil, B., Strobert, E., Gangappa, S., Weber, C. J., Pearson, T. C., Rajotte, R. V., and Larsen, C. P. 2006 Long-term survival of neonatal porcine islets in nonhuman primates by targeting costimulation pathways. Nat. Med. 12, 304-306.

Dahl, U., Sjodin, A., and Semb, H. 1996 Cadherins regulate aggregation of pancreatic beta-cells in vivo. Development 122, 2895-2902.

Dahlhoff, M., Dames, P. M., Lechner, A., Herbach, N., van Burck, L., Wanke, R., Wolf, E., and Schneider, M. R. 2009 Betacellulin overexpression in transgenic mice improves glucose tolerance and enhances insulin secretion by isolated islets in vitro. Mol. Cell Endocrinol. 299, 188-193.

Dor, Y., Brown, J., Martinez, O. I., and Melton, D. A. 2004 Adult pancreatic beta-cells are formed by self-duplication rather than stem-cell differentiation. Nature 429, 41-46.

Gannon, M., Shiota, C., Postic, C., Wright, C. V., and Magnuson, M. 2000 Analysis of the Cremediated recombination driven by rat insulin promoter in embryonic and adult mouse pancreas. Genesis. 26, 139-142.

Han, X. and Tuch, B. E. 2001 Cloning and characterization of porcine insulin gene. Comp Biochem. Physiol B Biochem. Mol. Biol. 129, 87-95.

Hanahan, D. 1985 Heritable formation of pancreatic beta-cell tumours in transgenic mice expressing recombinant insulin/simian virus 40 oncogenes. Nature 315, 115-122.

Hara, M., Wang, X., Kawamura, T., Bindokas, V. P., Dizon, R. F., Alcoser, S. Y., Magnuson, M. A., and Bell, G. I. 2003 Transgenic mice with green fluorescent protein-labeled pancreatic beta -cells. Am. J. Physiol Endocrinol. Metab 284, E177-E183.

Hering, B. J., Wijkstrom, M., Graham, M. L., Hardstedt, M., Aasheim, T. C., Jie, T., Ansite, J. D., Nakano, M., Cheng, J., Li, W., Moran, K., Christians, U., Finnegan, C., Mills, C. D., Sutherland, D. E., Bansal-Pakala, P., Murtaugh, M. P., Kirchhof, N., and Schuurman, H. J. 2006 Prolonged diabetes reversal after intraportal xenotransplantation of wild-type porcine islets in immunosuppressed nonhuman primates. Nat. Med. 12, 301-303.

Hotta, M., Tashiro, F., Ikegami, H., Niwa, H., Ogihara, T., Yodoi, J., and Miyazaki, J. 1998 Pancreatic beta cell-specific expression of thioredoxin, an antioxidative and antiapoptotic protein, prevents autoimmune and streptozotocin-induced diabetes. J. Exp. Med. 188, $1445-1451$.

Krakowski, M. L., Kritzik, M. R., Jones, E. M., Krahl, T., Lee, J., Arnush, M., Gu, D., Mroczkowski, B., and Sarvetnick, N. 1999 Transgenic expression of epidermal growth factor and keratinocyte growth factor in beta-cells results in substantial morphological changes. $J$. Endocrinol. 162, 167-175.

Londrigan, S. L., Brady, J. L., Sutherland, R. M., Hawthorne, W. J., Thomas, H. E., Jhala, G., Cowan, P. J., Kay, T. W., O'Connell, P. J., and Lew, A. M. 2007 Evaluation of promoters for driving efficient transgene expression in neonatal porcine islets. Xenotransplantation. $14,119-125$. 
MacKenzie, D. A., Hullett, D. A., and Sollinger, H. W. 2003 Xenogeneic transplantation of porcine islets: an overview. Transplantation 76, 887-891.

Martin, D. I. and Whitelaw, E. 1996 The vagaries of variegating transgenes. Bioessays 18, 919923.

Martin, J., Hunt, S. L., Dubus, P., Sotillo, R., Nehme-Pelluard, F., Magnuson, M. A., Parlow, A. F., Malumbres, M., Ortega, S., and Barbacid, M. 2003 Genetic rescue of Cdk4 null mice restores pancreatic beta-cell proliferation but not homeostatic cell number. Oncogene 22, 5261-5269.

Means, A. L., Ray, K. C., Singh, A. B., Washington, M. K., Whitehead, R. H., Harris, R. C., Jr., Wright, C. V., Coffey, R. J., Jr., and Leach, S. D. 2003 Overexpression of heparin-binding EGF-like growth factor in mouse pancreas results in fibrosis and epithelial metaplasia. Gastroenterology 124, 1020-1036.

Nagy, A., Gertsenstein, M., Vintersten, K., and Behringer, R. 2003 Manipulating the Mouse Embryo, Third Edition edn. Cold Spring Harbor, NY: Cold Spring Harbor Laboratory Press.

Postic, C., Shiota, M., Niswender, K. D., Jetton, T. L., Chen, Y., Moates, J. M., Shelton, K. D., Lindner, J., Cherrington, A. D., and Magnuson, M. A. 1999 Dual roles for glucokinase in glucose homeostasis as determined by liver and pancreatic beta cell-specific gene knockouts using Cre recombinase. J. Biol. Chem. 274, 305-315.

Schneider, M. R., Dahlhoff, M., Herbach, N., Renner-Mueller, I., Dalke, C., Puk, O., Graw, J., Wanke, R., and Wolf, E. 2005 Betacellulin overexpression in transgenic mice causes disproportionate growth, pulmonary hemorrhage syndrome, and complex eye pathology. Endocrinology 146, 5237-5246.

Schneider, M. R. and Wolf, E. 2009 The epidermal growth factor receptor ligands at a glance. J. Cell Physiol 218, 460-466.

Schneider, M. R., Zhou, R., Hoeflich, A., Krebs, O., Schmidt, J., Mohan, S., Wolf, E., and Lahm, H. 2001 Insulin-like growth factor-binding protein-5 inhibits growth and induces differentiation of mouse osteosarcoma cells. Biochem. Biophys. Res. Commun. 288, 435442.

Sjoholm, A. and Kindmark, H. 1999 Short- and long-term effects of beta-cellulin and transforming growth factor-alpha on beta-cell function in cultured fetal rat pancreatic islets. Endocrine. $11,189-193$.

Vasavada, R. C., Cavaliere, C., D'Ercole, A. J., Dann, P., Burtis, W. J., Madlener, A. L., Zawalich, K., Zawalich, W., Philbrick, W., and Stewart, A. F. 1996 Overexpression of parathyroid hormone-related protein in the pancreatic islets of transgenic mice causes islet hyperplasia, hyperinsulinemia, and hypoglycemia. J. Biol. Chem. 271, 1200-1208.

Verbeke, G. and Molenberghs, G. 2001 Linear Mixed Models for Longitudinal Data. New York: Springer.

Watanabe, M., Umeyama, K., Kawano, H. O., Izuno, N., Nagashima, H., and Miki, K. 2007 The production of a diabetic mouse using constructs encoding porcine insulin promoter-driven mutant human hepatocyte nuclear factor-1alpha. J. Reprod. Dev. 53, 189-200. 


\section{FIGURE LEGENDS}

Fig. 1 Generation of the PIP-hBTC construct. A: nucleotide sequence of the porcine insulin gene sequence employed in this study. The 5' flanking region is shown in lower case (the consensus TATA box is shown in bold). The transcription initiation site is underlined, the transcribed sequence is shown in upper case (cDNA sequence in bold). The translation initiation site is double-underlined and the sequence of the primers used to amplify the promoter is boxed. The sequence changed to a Hindlll site (AAGCTT) in the second primer is highlighted in grey. B: schematic representation of the construct employed to generate transgenic mice including the position of relevant restriction sites.

C: Western blot analysis of hepatocytes (1), kidney cells (2) and MIN-6 $\beta$-cells (3) transfected with the PIP-hBTC construct showing expression of human BTC exclusively in the $\beta$-cells. Staining of an unspecific band is shown as a loading control.

Fig. 2 Tissue and cell-specific expression of the PIP-hBTC construct in transgenic mice. A, B: RT-PCR analysis showing that transgene transcription is restricted to the pancreatic islets. Data in A are from L2 animals. C.P.: caudate putamen. C: Immunohistochemical staining of hBTC showing exclusive transgene protein expression within the pancreatic islets of L3 transgenic mice. D: Immunohistochemical detection of hBTC in the islets of transgenic mice as compared to non-transgenic control mice at higher magnification. Scale bars represent $500 \mu \mathrm{m}$ in $\mathrm{C}$ and $50 \mu \mathrm{m}$ in D. E,F: Simultaneous visualization of insulin, glucagon, and hBTC by multicolor immunofluorescence and confocal laser scanning microscopy in the islets of an adult PIP-hBTC (E), an adult non-transgenic control mouse (insert in E), and a PIP-hBTC fetus at day 17.5 of pregnancy (F).

Fig. 3 Glucose metabolism in BTC-tg mice. Intraperitoneal glucose tolerance test (A) revealed a significant reduction of the area under the curve (AUC, B) in PIP-hBTC transgenic mice from L2 and L3 as compared to control littermates. Values represent means \pm SEM of two independent experiments for $L 2$ and $L 3 .{ }^{*}: P<0.05$. 
A

$(-1495)$

gagttcagctgagctggctcccaggtcacctctctggg tcttggtgcccccagcatctcccaggctggccctgccetgggggtgcccttcccaccetg ccctgggccttgtggagggcaccctgggctcactgggaggcggtcggccctttccttccc gcaggatgtaagcaccagcctatcttccaggccctgcgccctccctgggtgcccccct cc tacctccagagccctgactctaggctcttaggatgtcggtcttggaaaactcctactcat ccgtcaagaccctcctgggaaa cccttccttcccagccccccaccctggatctgtgccc tttcagcctttgaggccacaaatgaggctgtttccaaaggttggaggcccctgggaaggg ctgacggccggcctcct cccctccaacccctgggecctgggctctgccctcatccagtct cctgccttgcacaccct ct catagaggcccccagatct tccctggctgcagacgggcetc aggaccccctgctgtcctgggaagccagggcccagctccttcctccgcgtggggtggggc ctccccacaggggcctgtcccgggggggtaccagagggt cacccccgcacatgggacagc gaagggaagcagtatgtcgtggggccgggtctgaaaggggtcagcagcaggggctccagg aggcaggggcactgagcggtacctgggggggaggtggtggggccacacccaggagtcctg tgccccccccact cccgccgtt ggagatgagaagcaggggccagcctgcgggtccetgag ttcagcgcccacccccccgccgcagcaccccggggtctcagcaggctgctgtgctggggg cgggggcgcttatggagccgggagcagccccccccccacggcctcggagcatctctgggg cctcagggatggaccggggtctgcaggcaggtgtcctct cgcgcccccactccctggget ataacgtggaagatgcggcccaagcccggtcggtttggcctttgtccccagccagtgggg acagcctggccctcaggctgctcgttaagactctaatgacctcgaggcccccagaggcgc tgatgacccacggagatgatcccgcaggcctggcagcagggaaatgatccagaaagtgcc acctcagcccccagccatctgccacccacctggaggccctcaggggccgggcgccggggg gcaggcgctataaagccggetgggcccagccg CCCCCAGCCCTCTGGGACCAGCTGTGTT CCCAGGCCACCGGCAAGCAGGTCTGTCCCCCTGGGCTCCCGTCAGCTGGGTCTGGGCTGT CCTGCTGGGGCCAGGGCATCTCGGCAGGAGGACGTGGGCTCCTCTCTCGGAGCCCTTGGG GGGTGAGGCTGGTGGGGGCTGCAGGTGCCCCTGGCTGGCCTCAACGCCGCCCGTCCCCCA GGTCCTCACCCCCCGCCATG

met

$(+1)$

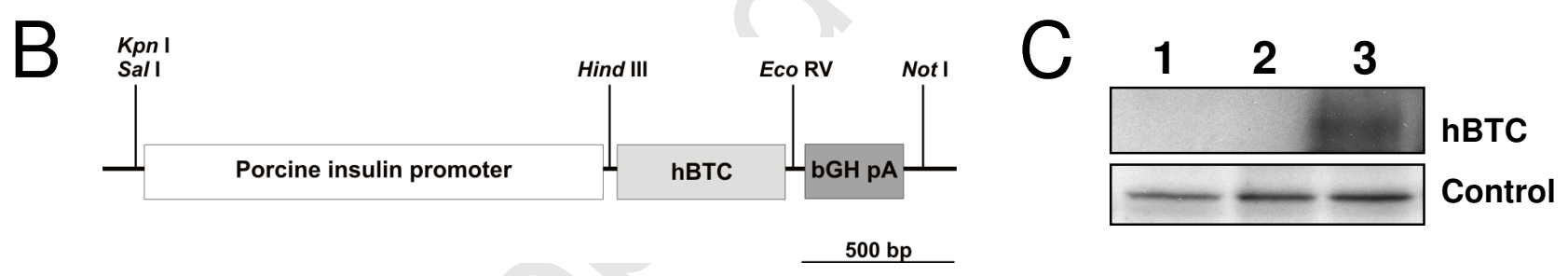



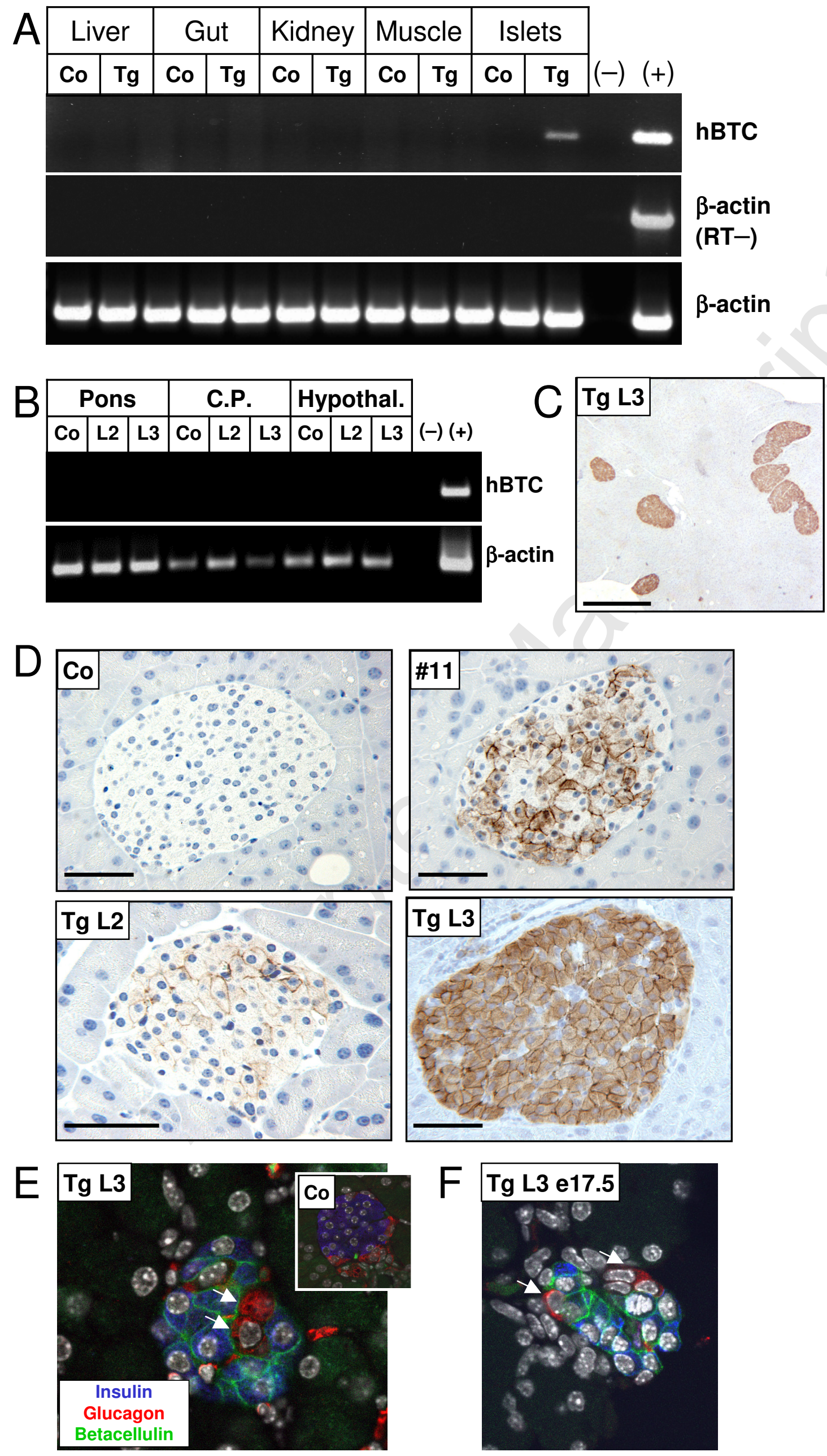

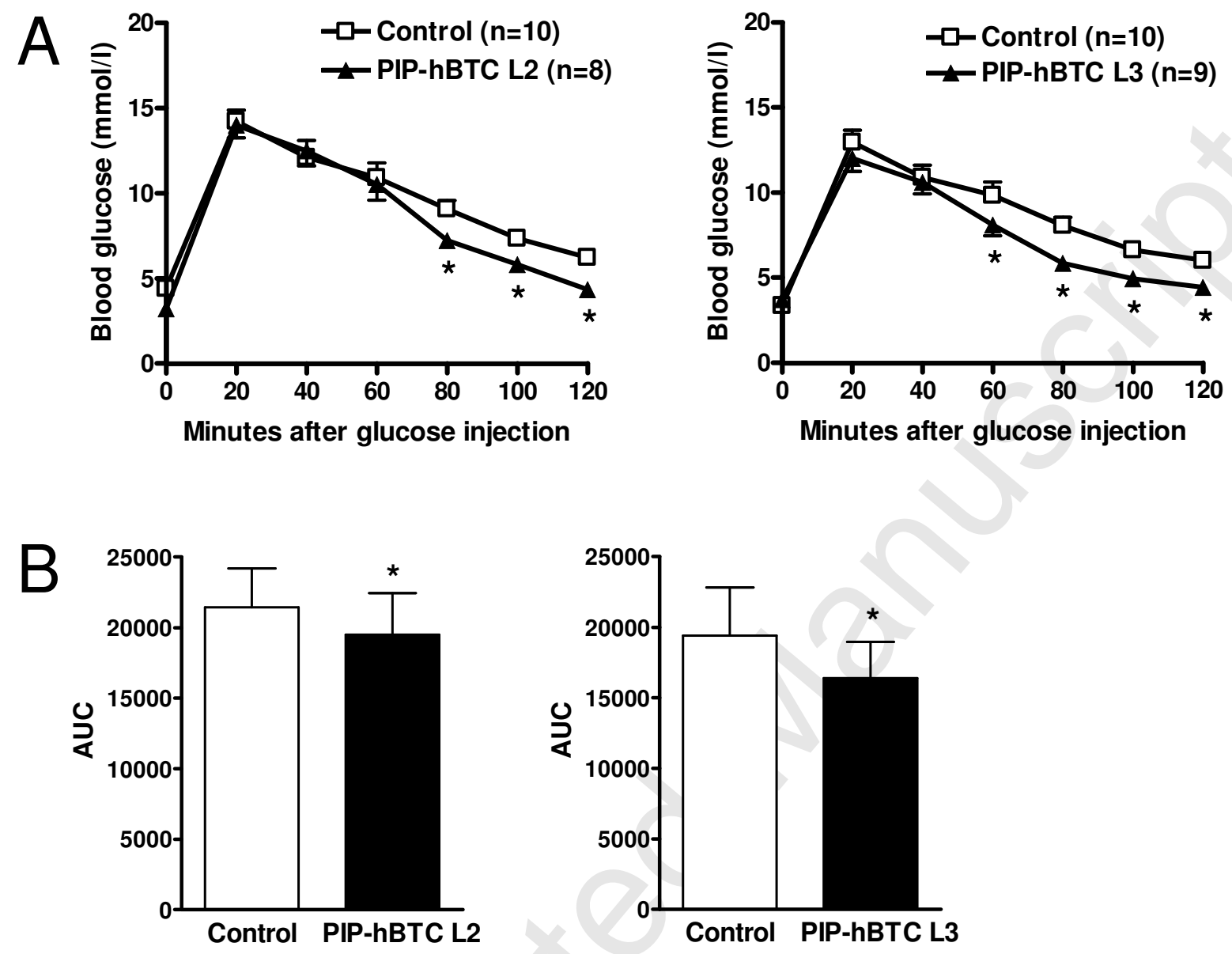